\title{
What We Learned from the Study of Exposed Population to PCBs and Pesticides
}

\author{
Pavel Langer ${ }^{1, *}$, Anton Kočan ${ }^{2}$, Mária Tajtáková ${ }^{3}$, Tomáš Trnovec ${ }^{2}$ and Iwar Klimeš $^{1}$ \\ ${ }^{1}$ Institute of Experimental Endocrinology, Slovak Academy of Sciences, Bratislava, Slovakia; ${ }^{2}$ Department of Toxic Or- \\ ganic Pollutants, Slovak Medical University, Bratislava, Slovakia; ${ }^{3}$ Clinic of Internal Medicine, Faculty of Medicine, \\ P.J. Šafárik University, Košice, Slovakia
}

\begin{abstract}
During previous fifteen years several field surveys were carried out in the large area subjected to environmental pollution by polychlorinated biphenyls and pesticides. The attention has been focused to the analyses of organochlorine (OCs) levels in environmental (superficial waters, air, soil, wildlife, foods) and human samples. Among adverse health effects the attention has been focused to thyroid volume and thyroid autoimmune disorders, pituitary-thyroid interrelations, metabolic disorders and diabetes in adults and to cognitive, behavioral and psychoneuromotoric disorders, impairment of hearing apparatus and dental defects in schoolchildren. Original data were obtained showing possible transgenerational transmission of certain adverse health effects possibly by previous prenatal and perinatal exposure of young adults to high organochlorine levels of their mothers. In participants from heavily polluted area with high blood organochlorine levels a significantly higher prevalence of adverse health signs was found compared to those from the area with considerably lower pollution. However, considerable attention was also paid to the problem of individual susceptibility to adverse health effects.
\end{abstract}

\section{INTRODUCTION}

Extensive evidence showed that long-range atmospheric transport of persistent organochlorinated pollutans is one of the main vectors for their translocation far away from the sides where they were produced, while the open ocean may serve as a final sink for such chemicals. Nowadays, there is a growing number of information about a global pollution by organochlorines (OCs) and about their adverse health effects. However, in addition to such global pollution there exist several reservoirs with considerably high OCs level resulting from dumping of industrial waste such a Baltic Sea, Great Lakes, Hudson Bay etc.

During the past 5-6 decades Slovakia has been also subjected to heavy industrial and agricultural pollution due to environmental negligence of previous regime. Since any scientific or public surveys have been strictly banned, the opportunity to search for possible adverse health effects became possible as late as in early nineties.

First survey carried out across the whole territory of Slovakia [1,2] showed considerably high serum levels of DDE (dichlorophenyl-dichloroethylene) with median of 6060 and range of 1300-34,800 ng/g lipid and for HCB (hexachlorobenzene) of 5380 and $160-23,200 \mathrm{ng} / \mathrm{g}$, respectively. At the same time the sum of 15 most abundant PCB congeners in western and central Slovakia was considerably lower (median 2630, range $460-4350 \mathrm{ng} / \mathrm{g}$ ) than that in eastern Slova-

*Address correspondence to this author at the Institute of Experimental Endocrinology, Slovak Academy of Sciences, Vlárska 3, 83306 Bratislava, Slovakia; Tel: +421-2-54772800; Fax: +421-2 -54774247;

E-mail: pavel.langer@savba.sk kia (median 3640, 1160-9200 ng/g) which apparently originated from the factory Chemko discharging the chemical waste to the Laborec river without any preventive measures. This further resulted in heavy waterborn and airborn pollution of air, soil, superficial and underground waters, fish, wildlife and food chain [3-7] Recently, also high level of the same substances was found in the cord blood and cord tissue in newborns from the same area [8-10].

Within the second survey in 1998 the $\Sigma 15$ PCBs in serum of 101 mostly exposed workers of Chemko factory from polluted area (POLL) was of $7300 \pm 871 \mathrm{ng} / \mathrm{g}($ mean $\pm \mathrm{SE})$ compared to that found in 205 referent adults $(1230 \pm 62$ $\mathrm{ng} / \mathrm{g}$ ) from the area located about 60 kilometers upwind and upstream which we selected as the area of background pollution (BCGR). Although we could not avoid a certain spillover between those two areas, still a striking difference in OCs level was found within the third extensive survey of 2046 adults in $2001[11,12]$, in which 1008 subjects from POLL showed $5 \%$ to $95 \%$ PCBs level range of 670-9100 $\mathrm{ng} / \mathrm{g}$ compared to 1038 subjects from BCGR with respective level of 350-1700 ng/g. Moreover, the respective levels of DDE were $550-8200$ vs. $350-4500 \mathrm{ng} / \mathrm{g}$ and these of HCB of 80-2900 and 100-2200 ng/g thus supporting unavoidable and persisting pesticide pollution of the area larger than that polluted by PCBs. Sum of dioxins, furans and dioxin-like coplanar PCBs in BCGR showed a median of $20.3 \mathrm{pg}$ TEQ/g lipid ( $25 \%$ to $75 \%$ level range of 15.7 to $27.4 \mathrm{pg}$ TEQ $/ \mathrm{g}$ ), while the respective values for POLL were $24.4 \mathrm{pg} T E Q / \mathrm{g}$ ( $25 \%$ to $75 \%$ range of 15.7 to $49.3 \mathrm{pg}$ TEQ/g), thus considerably higher level in upper two quartiles of POLL.

Since the beginning our attention has been focused to strikingly high PCBs level in fish from polluted Laborec river and Sirava lake (mean $\Sigma 15$ PCB congeners level found 
in planktivores was $223,550 \mathrm{ng} / \mathrm{g}$ lipid, while that in predators was as high as $375,430 \mathrm{ng} / \mathrm{g}$ ) which was found a main source of extremely high PCBs level in human serum [11]. Similarly, strikingly high values of PCBs, dioxins and furans were found in home-produced eggs, chicks and cow milk due to the access to contaminated soil as compared to these from large commercial farms [4].

At the same time, each survey has been also focused to the detection of possible adverse health effects. We were well aware that we are facing to multiple OCs pollution and thus also to their possible "cocktail effect" which still remains to be elucidated $[12,13]$. Although the interactive effects of all pollutants cannot be excluded, the appropriate toxic action of each of them and of its role cannot be satisfactorily quantified. Thus, it is difficult to specify to which extent each substance is responsible for a certain biological effect.

Since PCBs were the main target of this survey and also showed the largest range of values, they were used as a marker of the whole spectrum of OCs and thus all other data to be presented bellow were stratified in terms of PCBs level. However, from this follows that simultaneously changing levels of all other OCs should be always kept in mind. Although several statistical approaches are currently using sophisticated software, all findings thus obtained must not be necessarily compatible with biological interrelations. There certainly exists a huge black box between the exposure variables as inputs of the system (e.g. blood level of individual OCs) and outcome variables (e.g. blood level of hormones, antibodies etc.) as outputs. From such reason similar data, though obtained by sophisticated software, still seem to show rather superficial associations and some molecular approaches are needed such as, e.g., gene reporter systems etc.

\section{Adverse Effects of OCs on the Thyroid}

\section{A. Thyroid Volume and Thyroid Growth}

Increased goiter prevalence was found by palpation method in the subjects consuming rice oil poisoned by PCBs and furans in Japan [14] and also in Taiwan [15]. Since, however, due to a high consumption of sea food the iodine intake in those countries is high thus counteracting the thyroid growth, the above findings on possible goiter promoting effects of OCs appeared of interest. In contrast, it should be noted that even slight iodine deficiency in some OCs polluted area could bring false positive findings if increased thyroid volume would be ascribed to OCs effects.

Considering these reports, we carried out the survey of thyroid status in Chemko employees using a long term experience of one of us (M.T.) with thyroid ultrasound [16-20]. In addition, since increased frequency of thyroperoxidase antibodies (TPOab) has been found in workers exposed to polybrominated biphenyls [21], we also attempted to measure several thyroid antibodies.

Within the pilot survey [20] we found significantly higher thyroid volume (ThV) in 238 Chemko employees (median of $17.3 \mathrm{ml}$ ) as compared to that in 486 referent adults from much less polluted districts (median of $11.3 \mathrm{ml}$ ). From this it appeared that the increased $\mathrm{ThV}$ in those em- ployees could be related to their exposure to OCs. Although in that survey we still did not measure the level of PCBs in Serum, very high level in Chemko employees has been assumed from the data obtained previously [1].

Second pilot survey was carried out by joined chemical and medical staff in 1998 [22] and was aimed to define more accurately the borders of most polluted area. When comparing 101 Chemko employees with 205 adults from the area $60-70 \mathrm{~km}$ north which we selected as background pollution area (BCGR), we found significantly higher PCBs level $(6493 \pm 705$ vs. $1230 \pm 62 \mathrm{ng} / \mathrm{g}$; mean $\pm \mathrm{SE} ; \mathrm{p}<0.05)$ and thyroid volume $(16.19 \pm 0.59$ vs. $13.61 \pm 0.35 \mathrm{ml} ; \mathrm{p}<0.05$. Nevertheless, we observed that certain spillover in PCBs exposure existing between surrounding areas cannot be definitely avoided and thus we did not include 164 subjects with PCBs level of $3516 \pm 273 \mathrm{ng} / \mathrm{g}$ to the referent group, since they apparently were living in such "spillover" area.

Within the following PCBRISK survey (2001-04) a total of 2046 adults (834 men and 1212 women aged 21-75 years) were examined, among them 1008 from polluted area (POLL) and 1038 from BCGR as defined above [12]. In this survey we confirmed increased $\mathrm{ThV}$ associated with increasing level of OCs. For instance, the ThV of $11.15 \pm 0.26 \mathrm{ml}$ (mean \pm SE) in 407 adults in the $5^{\text {th }}$ PCB level quintile (5772 $\pm 387 \mathrm{ng} / \mathrm{g}$ lipid; mean $\pm \mathrm{SE}$ ) was significantly higher $(p<0.001)$ than that of $8.78 \pm 0.18 \mathrm{ml}$ found in 410 adults in the $1^{\text {st }}$ PCB level quintile $(485 \pm 5 \mathrm{ng} / \mathrm{g})$ and also significantly higher $(p<0.001)$ than that of $9.55 \pm 0.20 \mathrm{ml}$ found in 410 adults in the $3^{\text {rd }}$ PCB level quintile $(1102 \pm 6 \mathrm{ng} / \mathrm{g})$. At the same time, the level of DDE and HCB increased in parallel with that of PCB [12]. However, ThV also depends on the duration of exposure thus obviously increasing with age. Thus, we also showed the increase of $\mathrm{ThV}$ in large groups of age matched adults from polluted area compared to these from background pollution area, which was highly significant for the group of 21-40 years (288 vs. 291 subjects, resp.; $\mathrm{p}<0.01$ ), of $41-50$ years (379 vs. 364 subjects, resp.; $\mathrm{p}<0.0001)$ and of 51-60 years (365 vs. 282 subjects, resp.; $\mathrm{p}<0.0001)$. Thus, significant additional effect of OCs on ThV other than that of age was demonstrated [12]. General overview of those OCs and age effects on the $\mathrm{ThV}$ is also summarized in Fig. (1). It should be noted that this figure also shows a considerable individual susceptibility, since in each PCBs decile there is a large range of ThVs in subjects of each age group exposed to the same decile of PCBs level. Namely the upper limit of that range is considerably increasing with the number of decile. For instance, Fig. (1) shows 10 cases of $\mathrm{ThV}>15.0 \mathrm{ml}$ among 85 subjects aged $>50$ years in the lowest two deciles (first quintile) of PCB level, while significantly higher number of similar subjects (43 per 199 subjects; $p<0.05$ ) was found in the highest two deciles (fifth quintile). In addition, some possible threshold PCBs level as related to the increase of $\mathrm{ThV}$ was also discussed elsewhere [23].

However, it should be noted that due to a well monitored mandatory consumption of iodized salt since nearly 60 years ago Slovakia belongs to iodine replete countries as supported by the thyroid study of European schoolchildren [24], by the findings of satisfactory level of urinary iodine and/or low ThV within this [12] and our previous field surveys [17-20, 


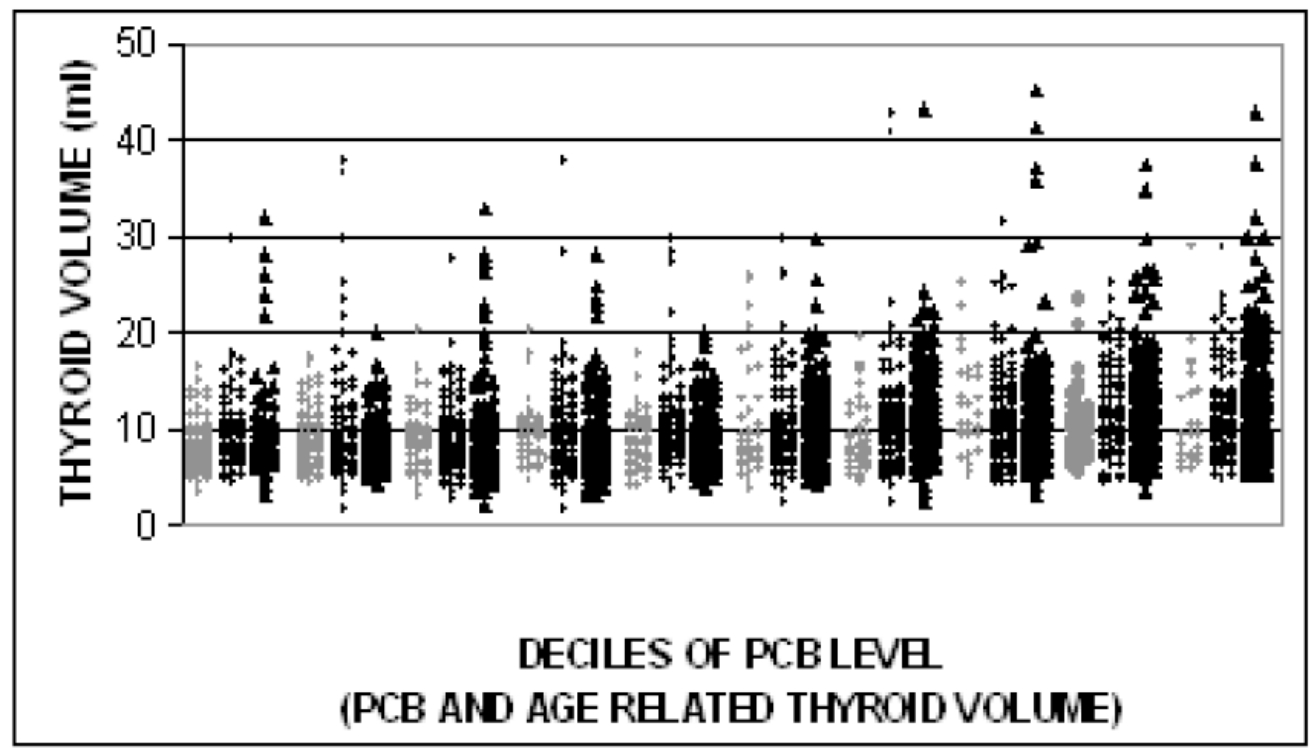

Fig. (1). Distribution of thyroid volume (ThV) in a total of 2046 adults (1212 females and 834 males) divided in three age groups (gray points $=<35$ years of age; black points $=36-50$ years of age; black triangles $=51-75$ years of age) as stratified in deciles of PCB level. Upper range limits of serum PCB level (ng/g serum lipid) in individual deciles are: $504-627-767-906-1,087-1,387-1,711-2,343-3,664-$ $101,413(90 \%$ of 10 th decile $=15,103)$.

22, 25]. Moreover, it should be noted that, although ThV was significantly higher in POLL, it was still relatively low in both POLL and BCGR areas. From this follows that such subtle differences in ThV related to different OCs level may be detected only by ultrasound.

\section{B. Possible Mechanism of OCs Effect on Thyroid Growth}

Although in rats fed very high doses of OCs (e.g. mg/kg body weight) several morphological [26-30] and ultrastructural changes [31,32] were observed, they must not necessarily be related to the growth of human thyroid. However, considerable morphometric changes in the thyroid of rat pups were found, if pregnant rats were administered tetrabromodiphenyl ether (PBDE) in a dose of 140 or $700 \mu \mathrm{g} / \mathrm{kg}$ [33].

Although the impaired thyroid growth could possibly result in the thyroid cancer ( $\mathrm{ThCa}$ ), only few possibly relevant data were found so far. Thus, three ThCa cases appeared among 5003 subjects from the village located nearby OCs producing factory [34], increased risk for ThCa was found in 13,482 workers exposed to OCs [35], increased mortality from ThCa appeared among 2885 OCs exposed workers [36] and in agricultural region of Minnesota with extensively used herbicides [37]. However, with the use of excellent Norwegian Cancer Registry [38] significantly elevated risk of ThCa was found in 40,849 women (174 cases per 1.210,683 person/years), whose spouses were employed in fishing, whaling or sealing work. Thus, it may be speculated that this finding could be related to high OCs level in fish from northern Atlantic.

Among 2046 adults within PCBRISK survey we found thyroid nodule by ultrasound in 98 cases. Among them 33 agreed with gammagraphy examination and some of them with following thin needle biopsy, while 5 agreed with surgical thyroidectomy because of very large nodules, but no
ThCa has been found. However, two cases of ThCa already treated were found by questionnaires among first degree relatives from POLL [12].

However, possible mechanism of OCs effect on the thyroid growth still remains to be elucidated. Perhaps the attention should be paid to possible thyroid growth effect of some OCs with estrogenic activity, e.g. of DDE and some PCB congeners $[39,40]$, since estrogen receptors (ER) were repeatedly found in normal and disordered thyroid $[41,42]$ and the binding of PCBs to such receptors in vitro was reported $[43,44]$. Moreover, via their specific Ah-receptor, some OCs may activate intracellular hormone signaling pathways including these of estrogens [45].

Estrogens and phytoestrogens were found to enhance the process of thyroid cell growth and tumorigenesis [46-48]. In thyroid cancer cells increased ERalpha expression was found, while that of ERbeta was either low or absent. Thus, estrogens may have opposite effect on the growth of thyroid cancer cells, depending on the balance between these two receptors [49]. Nevertheless, such ERalpha/ERbeta interplay in certain tissues represents one of decisive factors orienting the transcriptional mechanism of a target gene as related to the presence either of agonist or antagonist ligands among which could be even some OCs [50]. Human thyroid showed the potential for estradiol synthesis and autocrine or paracrine estrogen responsiveness which may contribute to such process [51]. This mechanism may be supported by higher incidence of $\mathrm{ThCa}$ in women during reproductive years compared to men or in postmenopausal women treated by estrogens for a long time compared to those not treated [52]. All such findings support the view that estrogens could contribute to the growth of malignant and possibly also normal thyroid which might be potentially valid also for OCs displaying estrogenic activity. Finally, close interrelations between female gender and thyroid may be supported by 
very well known high prevalence of all thyroid disorders (including cancer) which, in each ethnic, is at least about four times higher than that in males.

Finally, it was repeatedly observed that strongly lipophilic ortho-substituted PCBs congeners may dissolve in cell membrane, cause the increase in membrane fluidity and finally rapid death of thymocytes in vitro [53,54]. Although these experiments were performed in vitro, it cannot be excluded that, in subjects exposed for a long time, certain amount of PCBs could enter also the thyroid cell membranes and possibly influence the cross talk between thyroid membrane antigens and circulating lymphocytes. Such mechanism may further facilitate the development of autoimmune thyroiditis at least in hereditary predisposed individuals which also could contribute to the thyroid growth.

\section{OCs and Thyroid Hormones in Blood}

In rats two possible effects of OCs on thyroxine level were observed, one of them resulting from the displacement of T4 from the binding to transthyretin - main T4 carrier protein in rat plasma - as repeatedly reviewed $[55,56]$. However, the decrease of blood TT4 level was also considerably enhanced by the increase of T4 hepatic conjugation followed by increased biliary excretion resulting from the induction of hepatic UDP-glucuronyltransferase after feeding rats with high doses of PCBs or other glucuronidation inducers for few weeks $[57,58]$. In addition to a decrease of TT4 and TT3 level in blood, after feeding rats with PCBs also the increase of pituitary thyrotropin (TSH) was found $[59,60]$.

However, it should be noted that the doses of OCs (such as $\mathrm{mg} / \mathrm{kg}$ body weight) used in animals were by one or two orders of magnitude higher than the assumed intake in humans. Thus, there still remains a question whether such mechanisms could play some role in humans, since several controversial data on possible OCs effects on blood thyroid hormone level were published. It should be noted, first, that there is a problem to compare the data published in terms of lipid adjusted level of those highly lipophilic OCs with these using so called ppb level (e.g. "pars per billion" or $\mu$ g OCs per liter of wet serum). Since the latter reports mostly do not show the true lipid level in serum, the only way to transform their ppb level approximately to $\mathrm{ng} / \mathrm{g}$ lipid scale is to divide the value of $\mathrm{ng} / \mathrm{L}$ by $7.5 \mathrm{~g}$ which is the arbitrary median of total lipid level in serum.

It should also be recalled that $\mathrm{T} 4$ level in humans predominantly depends on the level of major thyroxine binding protein in human plasma (thyroxine binding globulin - TBG) - rather than on the thyroid function. From such reason total T4 estimation is neither recommended for clinical diagnostics by American Thyroid Association [61] nor for the screening of OCs effects on the thyroid by US Environmental Protection Agency [62]. Thus, it appears that the data obtained so far on the association of OCs with T4 level should be at least carefully interpreted, since they must not be related to the thyroid function at all. This refers both to accordantly reported findings on negative associations of OCs with T4 [63-66] or to these on either no changes [20, 67-69] or on a decrease of T4 level in subjects with increased OCs level [70]. Some other studies definitely reported very low and possibly subthreshold PCBs level such as $\Sigma 7 \mathrm{PCBs}$ level median of 62 and $95 \%$ of $226 \mathrm{ng} / \mathrm{g}$ (transformed) [71], the range of PCB-153 level of 30-292 ng/g [72] and $\Sigma 14$ PCBs level median of 45 and range of 20-160 $\mathrm{ng} / \mathrm{g}$ (transformed) [73]. Thus, there still remains a question whether the observed associations of such low OCs level with thyroid hormones result from the true effect of OCs or rather from some effects other than these of OCs.

Thus, total T4 estimation perhaps does not appear any relevant tool for the search of disrupting OCs effects on the thyroid status, while more appropriate information could be obtained by the estimation of FT4, FT3, TT3 and TSH, since these hormones are involved in the metabolic activity at the cellular level and/or in the regulation of pituitary-thyroid feed-back loop.

As concerns the associations of OCs with FT4 and TT3, among the studies in cohorts with relatively higher OCs level negative association of FT4 with PCBs (mean 200; $95 \%$ $\sim 420 \mathrm{ng} / \mathrm{g}$, transformed) was found [74], while positive association of FT4 and TT3 with DDE (mean $=204 ; 95 \%=$ $1230 \mathrm{ng} / \mathrm{g}$ ), but not with PCBs (mean $=212 ; 95 \%=566$ $\mathrm{ng} / \mathrm{g}$ ) was also reported [68]. In contrast, negative association of TT3 with $\Sigma 89$ PCBs (mean $=806$; maximum $=3104$ $\mathrm{ng} / \mathrm{g}$ ) [64], of TT3 with $\Sigma 16 \mathrm{PCBs}$ in males (mean $=1710 ; 75$ $\%=2550 \mathrm{ng} / \mathrm{g})[66]$ and that of TT3 with PCB-153 in females $($ median $=159 ;$ range $=16-776 \mathrm{ng} / \mathrm{g})$ was also found [75]. Surprisingly, any significant changes of TT4, TT3, FT4, FT3 in 110 Baltic fishermen with a considerable level of $\Sigma 18 \mathrm{PCBs}$ (mean $=1137 ; 90 \%=3617 \mathrm{ng} / \mathrm{g}$ ) and DDE $($ mean $=828 ; 90 \%=3152 \mathrm{ng} / \mathrm{g}$ ) were not claimed [76] and the same is true for 527 adults from Italy with a similar $\Sigma 24 \mathrm{PCBs}$ level (median $=713 ; 95 \%=3520 \mathrm{ng} / \mathrm{g}$ ) [69]. After weight loss in obese men significant increase of OCs released from adipose tissue was found together with a significant decrease of TT3 level [77] which, however, could result predominantly from the energy restriction rather than from the confounding effect of OCs.

Within PCBRISK survey we found highly significant correlation of $\Sigma 15$ PCBs with FT4 treated as continuous variable in all 2046 subjects $(r=0.104 ; p<0.001)$, while that with $\mathrm{HCB}$ was significantly negative $(\mathrm{r}=-0.059 ; \mathrm{p}<0.01)$ and no correlation was found with DDE. This seems to show possibly exclusive role of PCBs as related to the increase of FT4. However, if FT4 and TT3 levels were treated as categorical variables, in 232 subjects with relatively very low level of $\Sigma 15$ PCBs $(<530 \mathrm{ng} / \mathrm{g})$ we found significantly negative correlation with TT3 $(\mathrm{r}=-0.142 ; \mathrm{p}<0.05)$, while that with FT4 was above the limit of significance $(r=-0.109 ; \mathrm{p}<0.09)$. Moreover, the correlation in 691 subjects with $\Sigma 15 \mathrm{PCBs}$ categorical level of 531-1000 ng/g was fluctuating around zero, but became significantly positive after the upper range limit was increased to $2000 \mathrm{ng} / \mathrm{g}(\mathrm{p}<0.001$ for FT4 and $\mathrm{p}<0.05$ for TT3). Such fluctuating associations in different categories of FT4 and TT3 level could at least partly explain some discrepant findings obtained in several studies by others [78].

\section{OCs and Pituitary-Thyroid Interrelations}

So far, the association of various OCs with TSH level was found mostly positive, such as that of PCBs (mean of 214 , max. $505 \mathrm{ng} / \mathrm{g}$, transformed) with TSH in young Mohawks [74] or that of DDE but not of $\Sigma 18$ PCBs (median 159; 

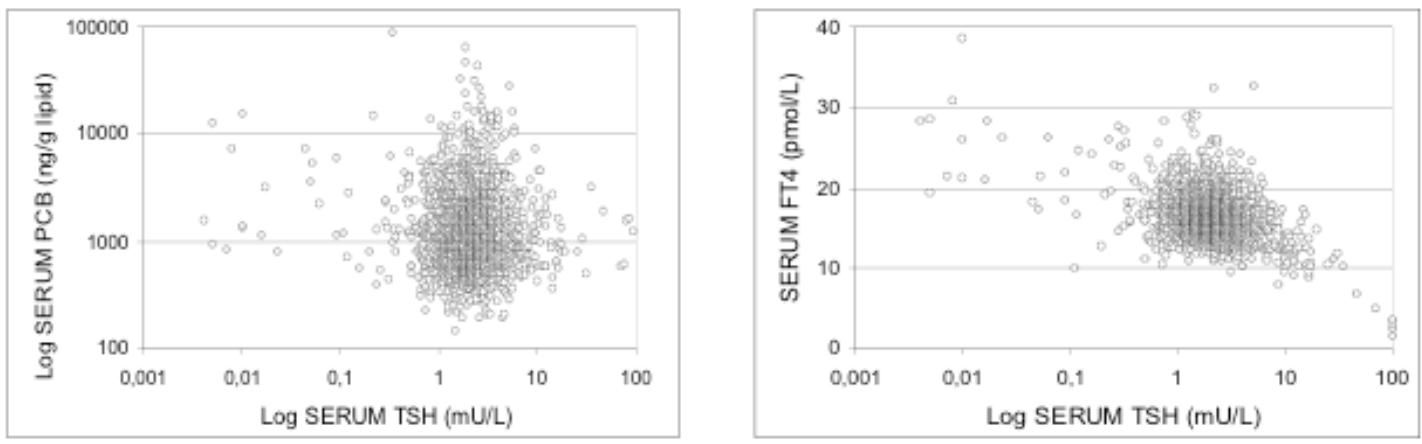

Fig. (2). Interrelation of serum TSH level with the sum of 15 PCB congeners (left panel) and free thyroxine (FT4) (right panel).

maximum $776 \mathrm{ng} / \mathrm{g}$ with TSH in Baltic fishermen [76]. Although the interrelations of PCBs (mean $\Sigma 89 \mathrm{PCB}$ for males of $626 \mathrm{ng} / \mathrm{g}$, transformed from $\mathrm{ppb}$ ) and DDE (mean for males of $613 \mathrm{ng} / \mathrm{g}$, transformed from ppb) with TSH in Great Lakes fish consumers were found inconsistent [63], in similar fish consumers positive association between PCBs (GM of $200 \mathrm{ng} / \mathrm{g}$ ) and TSH was later reported [65]. Positive relationship between DDE (median of 580, $95 \% 2140 \mathrm{ng} / \mathrm{g}$ ) and TSH was also found [79] as well as that of different individual PCB congeners with TSH in lakeside communities of Quebec [66]. Transient increase of serum TSH level in breast-fed babies of mothers exposed to dioxin was repeatedly reported from Netherlands [80, 81]. In contrast, however, negative association was found in adults between DDE (mean of 240, $95 \% 1230 \mathrm{ng} / \mathrm{g}$ ) and TSH [68], between PCBs (mean of $893 \mathrm{ng} / \mathrm{g}$, transformed) and TSH [70] and also between tetrabromodiphenyl ether (BDE-47) and TSH in Baltic fishermen [76]. Finally, no difference in TSH level between quartiles of PCBs level (median of 713, $95 \% 3521$ $\mathrm{ng} / \mathrm{g}$ ) in exposed adults from Italy was reported [69].

In spite of very large range of OCs level in a total of 2046 adults, we could not find any correlation of continuously treated TSH level either with PCBs (5\% to 95\% range of $417-5480 \mathrm{ng} / \mathrm{g}$ ) or with DDE (5\% to $95 \%$ range of $403-$ $6851 \mathrm{ng} / \mathrm{g}$ ) [23, 78]. However, if TSH level was treated as categorical variable, there appeared considerable clustering of very high PCBs levels in a small group of 48 subjects with TSH level $<0.50 \mathrm{mU} / \mathrm{L}$, among which $16 / 48$ subjects $(33.3$ $\%$ ) had PCBs level $>3000 \mathrm{ng} / \mathrm{g}$, while in remaining subjects with TSH >0.50 mU/L such number was 256/1998 (12.8\%; $\mathrm{p}<0.001)$.

When searching further for additional signs of hyperthyroidism (e.g. increased FT4 plus increased TT3) among the subjects with very high PCBs level, we identified a total of 13 cases ( 9 females and 4 males) with very low TSH level (mean $\pm \mathrm{SE}=0.16 \pm 0.05 \mathrm{mU} / \mathrm{L}$ ). Their average FT4 level of $23.34 \pm 3.71 \mathrm{pmol} / \mathrm{L}$ was higher than the upper limit of normal reference range $(22.0 \mathrm{pmol} / \mathrm{L})$ and all TT3 levels (mean of $2.56 \pm 0.25 \mathrm{nmol} / \mathrm{L}$, range of $2.14-3.13 \mathrm{nmol} / \mathrm{L}$ ) were higher than the median of normal reference range of 2.10 $\mathrm{nmol} / \mathrm{L}$ ). We called these cases "high PCBs related subclinical hyperthyroidism" since they showed fundamental laboratory signs of hyperthyroidism (very low TSH and very high FT4 and TT3), while their normal or slightly increased body mass index (mean \pm SE 26.2 \pm 0.7 ) was compatible with more or less balanced possibly subclinical metabolic state [82], though more detailed clinical examinations were not done [78]. This view is in agreement with recently suggested revision of thyroid diseases classification by Monaco [83] who admitted that "environmental factors can affect thyroid function without a modification of thyroid morphology" and defined "subclinical hyperthyroidism as an asymptomatic state in which circulating FT3 and FT4 are normal, but serum sensitive TSH is suppressed which shows a mild stage of thyroid hyperfunction".

Thus, from our findings it may be concluded that TSH level tends to decrease with increasing level of PCBs which is contrasting to several findings of increased TSH level by others as referred above. Such view may be supported by Fig. (2) which shows a general trend between the decreasing level of TSH and increasing level of PCBs (left panel) and of FT4 (right panel). However, similarly to Fig. (1), this figure possibly also shows the important role of individual susceptibility in the development of adverse health effects related to PCB. Thus, the left panel shows a tremendous number of cases with PCB level of 1000 to $10,000 \mathrm{ng} / \mathrm{g}$, while only very few of them had TSH level $<0.5 \mathrm{mU} / \mathrm{l}$. The right panel further shows that several of those cases with TSH level $<0.5$ $\mathrm{mU} / \mathrm{l}$ also have increased level of FT4. As explained in detail above, we previously identified 13 cases with very high PCB and, at the same time low TSH and high FT4 [78]. Since a significant positive correlation between PCBs with both FT4 and TT3 was demonstrated previously [23, 78], it may be concluded that increasing PCBs possibly result in increasing FT4 by disrupting the equilibrium between total and free thyroxine in plasma. This further possibly results in increased input of FT4 to the cells and increased intracellular T4 to T3 conversion including pituitary cells which contributes to a final decrease of TSH.

In general, current opinions on the interrelation between TSH level as a major diagnostic tool and thyroid function are based on categorical reference intervals which were recently set to $<0.4 \mathrm{mU} / \mathrm{L}$ for hyperthyroidism and $>2.5 \mathrm{mU} / \mathrm{L}$ for hypothyroidism [84-86], although considerable controversies namely on the upper level (which about 10 years ago was still $4.5 \mathrm{mU} / \mathrm{L}$ ) are still going on. Thus, within the Colorado Thyroid Disease Prevalence Study 90.1 \% among of 24,337 subjects had TSH level 0.3-5.1 mU/L [87], while within the NHANES III about $90 \%$ participants had TSH level between 0.5 and $2.5 \mathrm{mU} / \mathrm{L}$ [84]. However, because of low number of cases with very low TSH level in our cohort we 
arbitrarily increased the hyperthyroid cut/off level from 0.4 to $0.5 \mathrm{mU} / \mathrm{L}$.

From this follows that TSH level should not be treated as a continuous variable. Since a great majority of subjects have TSH level densely pressed within a very narrow range between about 0.5 and $4.5 \mathrm{mU} / \mathrm{L}$, while nearly all of them show a normal thyroid function, it seems paradoxical to search for some pathological associations within such densely pressed cluster of predominantly normal data (see also Fig. 2).

\section{E. OCs and Subclinical Thyroid Disorders}

Countless reports exist on the increased prevalence of immune system disorders in the population exposed to various OCs, among them on increased prevalence of otitis media in Inuit children [88], decrease of vaccine response in children from Faroe Islands [89], decrease of IgG in exposed population after industrial accident in Italy [90], in North Carolina farmers exposed to DDE [91] or in OCs exposed polar bears [92]. Multiple immune system lesions also occurred after mass human poisoning by HCB in Turkey [93].

It should be underlined that overwhelming majority of thyroid diseases also shows autoimmune origin. Thus, hyperthyroidism results from the stimulation of thyroxine release from the thyroid by the action of pathological thyrotropin receptor antibodies [TRab] which further results in an overstimulation of thyroxine release from the thyroid. In such a case the pituitary-thyroid feed-back system is suppressed by high level of thyroid hormone and hence the thyroid is solely under the control of those antibodies.

In contrast, hypothyroidism results from cytotoxic effects of thyroperoxidase and/or thyroglobulin antibodies (TPOab and TGab, respectively) which further result in a gradual destruction of thyroid tissue and impairment of thyroid function. From epidemiological view it is necessary to note that both such major diseases could be subclinical or latent and thus unrecognized for years or even decades as appeared is especially true for hypothyroidism. From such reason it is of special importance to search predominantly for the signs of subclinical hypothyroidism (e.g. positive TPOab and TGab level, thyroid hypoechogenicity by ultrasound and increasing TSH level) and these of subclinical hyperthyroidism (namely low level of TSH and high level of FT4, TT3 and TRab). Recently the pathogenesis of autoimmune thyroid diseases resulting from the interaction between susceptibility genes and environmental triggers has been extensively reviewed [94].

As mentioned above, anti-microsomal antibodies (this is an obsolete term for TPOab) were found in workers employed in PBB factory [21]. As far as we are aware, since that time no findings on increased thyroid antibody prevalence in humans exposed to OCs were published. However, the association of TPOab with increased PCBs level was found within all our surveys [12, 20, 22, 23]. Although the absolute number of subjects with positive TPOab level was much higher in females, the difference between those highly exposed and less exposed was much higher in males [12, 23]. Although TPOab level in serum is the marker of autoimmune process and possible predictor of overt hypothyroid- ism, each subject with actual positive value must not yet be clinically hypothyroid. However, the stage of progressing hypothyroidism may be seen by ultrasound which reveals the extent of thyroid injury by hypoechogenicity of thyroid ultrasound image $[95,96]$. Actually, we found significantly higher coincidence of positive TPOab with hypoechogenicity in 5th versus 1st quintile of serum PCBs level in males (7.2 $\%$ vs. $1.0 \%$; $\mathrm{p}<0.03$ ), while that in females was not significant $(14.7 \%$ vs. $11.3 \%)$, although in terms of absolute numbers it was much higher than that in males [12]. However, the stage of overt hypothyroidism is finally indicated by the increase of TSH level over the certain range, although there currently appears some disagreement between epidemiological and clinical views. Thus, as shown above, recent epidemiological views on the lower range of hypothyroid TSH level are based predominantly on the finding of only about $10 \%$ general population with the level $>2.5 \mathrm{mU} / \mathrm{L}$ [84]. Although the advocates of this view admit that the distribution of TSH level in the large population shows a skewed curve with a long tail toward the higher TSH values, they underline that the values greater than $2.5 \mathrm{~m} / \mathrm{L}$ are predictive of evolution into overt hypothyroidism [86]. In contrast, several current clinical views suggest that the treatment of hypothyroidism by thyroxine is advisable for those with TSH level >10 mU/L, while those with TSH of 4 to $10 \mathrm{mU} / \mathrm{L}$ still represent a dilemma which should be guided by careful clinical evaluation, since the decisions based on TSH, T4 and T3 measurements seem to be somewhat arbitrary [97].

Thus, it appears that thyroid autoimmunity should be included in the cluster of immune system injuries which seem to be one of major adverse health effects of OCs. Nevertheless, there are some problems related to thyroperoxidase itself which should be at least briefly discussed, though they are out of the scope of this review. Thus, so far any generally accepted international standard of TPO apparently does not exist [98]. Moreover, thyroperoxidase antibodies in human sera are polyclonal and their fingerprints, which may be genetically determined, recognize several conformational immunogenic epitopes located on thyroperoxidase molecule which are also genetically determined $[99,100]$. From this follows, that there are several commercial kits which are using different TPO preparations, different epitopic specificity of antibodies and different units. Other problem is the analytical and clinical cut/off level. Thus, the clinical cut/off usually means that $95 \%$ of clinically sick patients will show the values higher than cut/off, while $95 \%$ healthy blood donors will show the values lower than cut/off in contrast, analytical cut/off shows the minimal level which is significantly different from zero and thus some TPOab in blood are already present thus predicting a possibility of already existing subclinical and later possibly of overt disorder. It seems that from epidemiological view the analytical cut/off could be more important than that clinical one, since it shows the extent of the spawn predicting a possible future development of subclinical thyroid disorders. In our surveys we used automatic electrochemiluminiscent immunoassay (Elecsys, Roche, Germany) and the cut/off level of $37 \mathrm{U} / \mathrm{ml}$ which was slightly higher than the clinically recommended value of 34 $\mathrm{U} / \mathrm{ml}$, so the values we referred are both analytically and clinically positive. 
Recently TPOab levels higher than the normal reference range were found in 18 among 47 breast fed young Akwesasne Mohawks (median age of 17.6 years) [101] who had significantly higher levels of HCB, DDE and all groups of PCB congeners, while no one case was found among 67 of those non-breast fed.

\section{Miscellaneous Adverse Metabolic and Thyroid Health Signs}

\section{A. OCs and Diabetes}

Although some occupational surveys reported the association of OCs exposure with diabetes, among the first plausible findings were these on increased fasting and 2-hr postprandial glucose level as obtained in Vietnam veterans spraying Agent Orange containing TCDD (2,3,7,8tetrachloro-dibenzo-dioxin) [102], increased prevalence of diabetes together with serum glucose and insulin abnormalities [103] as well as on the association of increased plasma insulin and insulin resistance with high TCDD level [104, 105].

The association of serum OCs level with diabetes was also found in participants of the NHANES III study $[106,107]$. Increased association of self-reported diabetes with serum level of PCB-153 and DDE was observed in large groups of Swedish adults [108, 109] and also in women involved in pesticide related activities within the Agricultural Health Study [110]. Among important findings is that of highly increased odds ratio for diabetes in 24-year followup study of Yucheng women in Taiwan [111].

The data obtained within the PCBRISK study by the estimation of fasting glucose level in 2046 adults and oral glucose tolerance test in 1220 of them showed increased prevalence of impaired fasting glucose, impaired glucose tolerance and diabetes mellitus significantly associated with increasing PCBs level in serum as summarized in preliminary reports $[112,113]$.

However, the mechanisms resulting in such associations are still lacking. Nevertheless, reduced glucose transport activity in adipocytes of dioxin treated mice was found together with reduced copy numbers of glucose transporter GLUT4 and its mRNA. This finding raised the possibility that dioxin might gradually reduce the production of glucose transporters and thereby cause progressive insulin resistance [114]. It is well known that toxic effects of OCs are apparently mediated via the binding with a specific Ah-receptor (AhR) whose ligand binding subunit also acts as a ligand activated transcription factor. Among heterodimerization partners of such subunit are AhR nuclear translocator (Arnt) and nuclear transcription factor kappa B $(\mathrm{NF} \kappa \mathrm{B})$. It was also suggested that dioxin specific AhR may promote diabetogenic effect by antagonizing the function of peroxisome proliferator activated receptors (PPARs) [115] which were also found to be linked to cellular proliferation, differentiation and apoptosis as well as to obesity, diabetes, atherosclerosis, inflammation, cancer and aging. However, it was stressed that the responsive genes required for TCDD toxicity still have to be defined, although the induction of Cyp1A1 itself appeared a significant event in the toxicity pathway of OCs [116]. Recently, however, it was demonstrated that the in- creased ratio of mRNA of GLUT 4 and $\mathrm{NF \kappa B}$ in adipose tissue obtained from Vietnam veterans appeared the most sensitive and reliable indicator of dioxin induced diabetes particularly at very low exposure levels [117].

\section{B. OCs and Prevalence of Multiple Adverse Health Signs}

In addition to aforementioned impaired glucose metabolism we also found significant positive association of major OCs with triglycerides, cholesterol, BMI, thyroid volume, TPOab [12] as well as with FT4, TT3 and TSH treated as categorical variables [78]. Using these data we arbitrarily defined several adverse health signs such as increased ThV ( $>75$ th percentile), positive TPOab $(>37 \mathrm{U} / \mathrm{ml})$, positive TRab $(>1.7 \mathrm{mU} / \mathrm{ml})$, increased FT4 $(>19 \mathrm{pmol} / \mathrm{L})$, increased TT3 (>2.1 nmol/L), TSH in hypothyroid $(>4.0 \mathrm{mU} / \mathrm{L})$ or hyperthyroid $(<0.5 \mathrm{mU} / \mathrm{L})$ range, increased thyroglobulin $(>40 \mathrm{ng} / \mathrm{ml})$, increased fasting glucose $(>5.6 \mathrm{mmol} / \mathrm{L})$ and insulin $(>10 \mathrm{mIU} / \mathrm{ml})$ as well as increased cholesterol $(>6.0$ $\mathrm{mmol} / \mathrm{L})$, triglycerides $(>2.0 \mathrm{mmol} / \mathrm{L})$ and $\mathrm{BMI}(>75$ th percentile).

Fig. (3) shows the numbers of individuals from POLL $(\mathrm{n}=1008)$ and BCGR $(\mathrm{n}=1038)$ as sorted in terms of increasing number of adverse health signs per person. As shown, the prevalence of subjects with 0 or 1 adverse signs was nearly twice as high in BCGR (272/1038 vs. 125/1008; $\mathrm{p}<0.001)$, while, inversely, more than twice as high prevalence was found in POLL: for subjects with 6 or 7 (195/1008 vs. $84 / 1038 ; \mathrm{p}<0.001)$ and with 8 or 9 adverse signs $(54 / 1008$ vs. $22 / 1038 ; \mathrm{p}<0.001)$. Hence it appeared that in more exposed population the number of subjects with more adverse signs was significantly higher.

\section{Prenatal Exposure to OCs and Possible Transgenera- tional Transmission of OCs Related Adverse Health Effects}

As repeatedly reviewed [118-121], considerable attention has been focused to early and delayed effects of prenatal and perinatal OCs exposure on children and adolescents. Within the birth cohort study which followed PCBRISK survey in the same POLL area high levels of PCBs, pentachlorophenol, hydroxy-PCBs [8-10] and methylsulphone-PCBs [10] were recently found in cord blood which showed a considerable exposure of the third generation born in that area since the start of PCBs production in 1955. In addition, the first evidence to date on the association of PCBs exposure in neonates with decreased thymus volume was provided [122] and the tight connection between the development of immune and central nervous system during prenatal life was described which may play a role in future neurobehavioural disorders [123].

In agreement with the data by others [124-127], the cross-sectional examination of 435 children 8-9 year-old within PCBRISK study showed considerably wide range of OCs exposure and negative association between the serum PCBs level and performance in several neuropsychological tests [128]. In addition, increase of hearing threshold at the frequencies of $250-2000 \mathrm{~Hz}$ as well as a decrease of the amplitude of transient otoacoustic emissions with increasing PCBs level was observed [129] and the proportion of different types of developmental enamel defects, demarcated or 


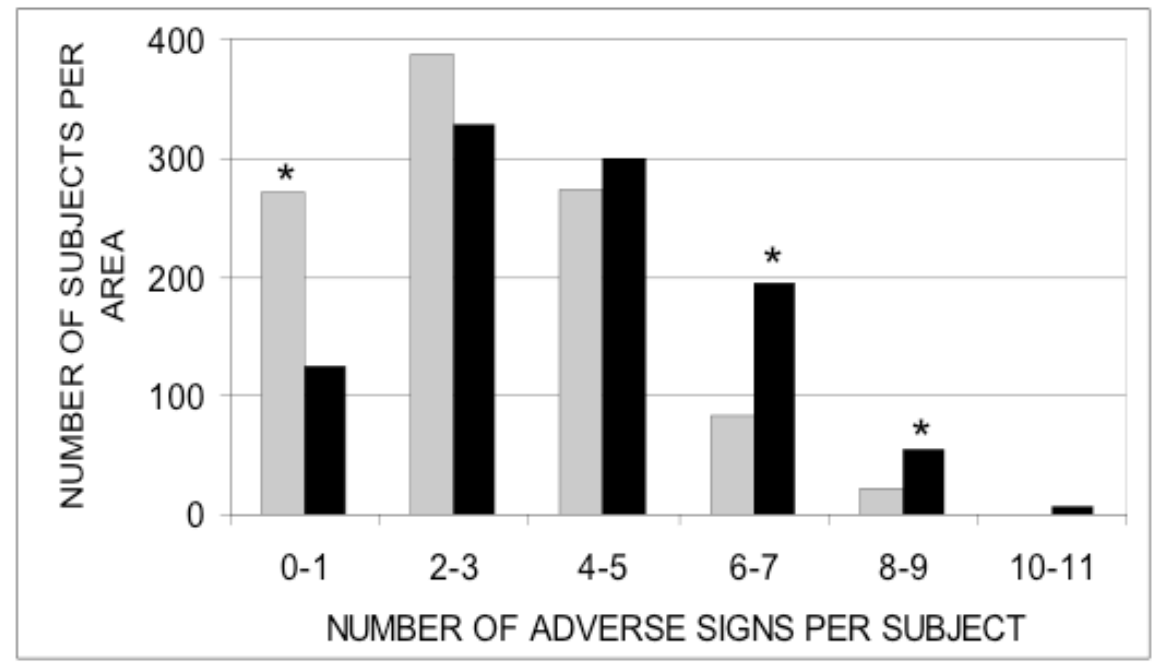

Fig. (3). Absolute number of subjects (y axis) belonging to groups of subjects with increasing number of multiple adverse health signs (x axis) in the area of background pollution (gray columns) and in the polluted area (black columns).

diffuse opacities and/or hypoplasia significantly correlated with serum PCBs level [130].

In 223 young adult males and females (aged 21-35 years) from POLL who were participants of PCBRISK survey we found significantly higher prevalence of TPOab, TRab, increased $\mathrm{ThV}$ and impaired fasting glucose as compared to 231 of their counterparts from BCGR. However, although the level of all major OCs (such as PCBs, DDE and HCB) in those young adults from POLL was significantly higher than that in those from BCGR, it was still about a half of that found in 533 subjects from POLL (aged 41-55 years) thus representing the generation of their parents. Since those young adults from POLL were born during the period of high environmental pollution (1966-1980) it was hypothesized that the adverse effects could result from the prenatal exposure rather than from their own exposure during postnatal life.

As shown in Table 1, among 116 young females from POLL a total of 44 were selected with nearly the same levels of PCBs, DDE and HCB as these in 137 of their counterparts from BCGR. In such selected group called "PCB adjusted young females" still significantly higher prevalence of TPOab ( $\mathrm{p}<0.001)$, TRab $(\mathrm{p}<0.01)$, IFG $(\mathrm{p}<0.001)$ and ThV $(\mathrm{p}<0.01)$ was found as compared to young females from BCGR. In addition, entirely the same differences were found in "PCB adjusted young males" from POLL [131]. Hence it appeared that the assumption on possible role of prenatal and perinatal exposure in the development could be supported. However, since possibly also some epigenetic component could participate in the final outcome, the data obtained may be compatible with several present views and findings on epigenetic transgenerational transmission of endocrine disruptors action [132,133].

\section{CONCLUSIONS, PERSPECTIVES AND VISIONS}

It seems that the global pollution by unfriendly chemicals will be hardly cleaned up. There possibly appears no other way but to live with them and to let them to pioneer new pathways in the labyrinth of our cells and molecules and thus
Table 1. Serum Level of PCB, DDE and HCB (ng/g lipid) in all Young Females (Aged 21-35 Years) from Background Area (BCGR), Polluted Area (POLL) as well as in the Group of 44 Females Selected from Polluted Area (POLL-ad) which Showed Approximately the Same Mean Level of PCB, DDE and HCB as these in BCGR

\begin{tabular}{|c|c|c|c|}
\hline \multirow{3}{*}{ Parameter } & \multicolumn{3}{|c|}{ Females 1 - 35 Years } \\
\hline & \multicolumn{2}{|c|}{ All Females } & \multirow{2}{*}{\begin{tabular}{|c|} 
PCB Adjusted \\
Polluted \\
Area (POLL-ad)
\end{tabular}} \\
\hline & $\begin{array}{c}\text { Background } \\
\text { Area (BCGR) }\end{array}$ & $\begin{array}{c}\text { Polluted } \\
\text { Area (POLL) }\end{array}$ & \\
\hline $\begin{array}{l}\text { Age (years; mean } \pm \\
\text { SD) }\end{array}$ & $27.6 \pm 4.4$ & $25.9 \pm 4.2^{\mathrm{A}}$ & $24.9 \pm 3.5^{\mathrm{A}}$ \\
\hline Number of cases & 137 & 116 & 44 \\
\hline $\begin{array}{c}\mathrm{PCB}-\text { mean } \pm \mathrm{SE} \\
(\mathrm{ng} / \mathrm{g})\end{array}$ & $566 \pm 37$ & $1493 \pm 134^{\mathrm{E}}$ & $649 \pm 20^{\mathrm{D}}$ \\
\hline $\begin{array}{c}\mathrm{DDE}-\text { mean } \pm \mathrm{SE} \\
(\mathrm{ng} / \mathrm{g})\end{array}$ & $791 \pm 42$ & $1385 \pm 104^{\mathrm{E}}$ & $963 \pm 95^{\mathrm{D}}$ \\
\hline $\begin{array}{c}\mathrm{HCB}-\text { mean } \pm \mathrm{SE} \\
(\mathrm{ng} / \mathrm{g})\end{array}$ & $270 \pm 15$ & $326 \pm 30^{\mathrm{D}}$ & $198 \pm 16^{\mathrm{D}}$ \\
\hline $\begin{array}{c}\text { TPOab }>37 \mathrm{IU} / \mathrm{ml} \\
(\%)\end{array}$ & $\begin{array}{c}15 / 137=10.9 \\
\%\end{array}$ & $\begin{array}{c}43 / 116=37.1 \\
\%^{\mathrm{C}}\end{array}$ & $18 / 44=40.9 \%^{\mathrm{C}}$ \\
\hline TRab > $2.0 \mathrm{IU} / \mathrm{ml}(\%)$ & $9 / 137=6.5 \%$ & $\begin{array}{c}20 / 116=17.2 \\
\%^{\mathrm{B}}\end{array}$ & $10 / 44=22.7 \%^{\mathrm{B}}$ \\
\hline $\mathrm{ThV}(\mathrm{ml} ;$ mean $\pm \mathrm{SD})$ & $7.52 \pm 2.37$ & $8.31 \pm 2.62^{\mathrm{D}}$ & $8.74 \pm 2.49^{\mathrm{E}}$ \\
\hline $\begin{array}{c}\mathrm{IFG}(5.6-6.9 \mathrm{mmol} / \mathrm{l} \\
; \%)\end{array}$ & $\begin{array}{c}33 / 137=24,1 \\
\%\end{array}$ & $\begin{array}{c}44 / 116=37.9 \\
\%^{\mathrm{A}}\end{array}$ & $18 / 44=40.9 \%^{\mathrm{C}}$ \\
\hline
\end{tabular}

Statistical differences between either all or adjusted females from polluted area vs. females from background area: - chi-square test: ${ }^{\mathrm{A}}=\mathrm{p}<0.05 ;{ }^{\mathrm{B}}=$ $\mathrm{p}<0.01 ;{ }^{\mathrm{C}}=\mathrm{p}<0.001 ;$ t-test: ${ }^{\mathrm{D}}=\mathrm{p}<0.05 ;{ }^{\mathrm{E}}=\mathrm{p}<0.01$.

to disrupt our inherited mechanisms regulating the sophisticated interplay between several systems and organs of our 
body. They already discovered epigenetic route to our DNA for sure and thus learned how they could influence our genome much earlier than our scientists did. Thus, they possibly play there already a role of the spawn or mycelium which will be manifested in the next generations.

\section{ACKNOWLEDGEMENTS}

Great part of this work was supported by 5th Framework Program of European Commission (PCBRISK - QLK42000-00488) and also by MVTS/QLK4-2000-00488 fund of Slovak Academy of Sciences and by Ministry of Environment, Slovak Republic (Contract No. 65/97/2.4). The support of pilot surveys from Merck Slovakia, Children Fund (Geneva) and Henning Berlin is greatly acknowledged. The authors wish to express their cordial gratitude to all colleagues who participated in the field surveys, endless blood analyses, preliminary evaluations of raw data and participated as co-authors in a series of previously published papers on individual partial findings and who are not quoted in this review because of condensed references, e.g. Juraj Koška, Lucia Kšinantová, Richard Imrich, Miloslava Hučková, Elena Šeböková, Daniela Gašperíková, Jozef Ukropec, Alica Mitková and Katarína Bučková. Kind co-operation of 28 district practitioners and public health authorities from Michalovce, Svidník and Stropkov districts in the organization of field surveys and recruiting participants is greatly acknowledged.

\section{LIST OF ABBREVIATIONS USED}

\begin{tabular}{|c|c|c|}
\hline BCGR & $=$ & control area of backhround pollution \\
\hline DDE & $=$ & dichlorodiphenyl dichloroethylene \\
\hline ER & $=$ & estrogen receptor \\
\hline FT3 & $=$ & free triidoothyronine \\
\hline FT4 & $=$ & free thyroxine \\
\hline GM & $=$ & geometric mean \\
\hline $\mathrm{HCB}$ & $=$ & hexachlorobenzene \\
\hline OCs & $=$ & organochlorines \\
\hline PBB & $=$ & polybrominated biphenyls \\
\hline PCB & $=$ & polychlorinated biéhenyls \\
\hline PCBRISK & $=$ & acronym of the project \\
\hline PCDDs & $=$ & polychlorinated dibenzo-dioxins \\
\hline PCDFs & $=$ & polychlorinated dibenzo-furans \\
\hline POLL & $=$ & polluted area \\
\hline PCBRISK & $=$ & acronyme of the project \\
\hline SIR & $=$ & Standard Incidence Rate \\
\hline SPEECD & $=$ & acronyme of the project \\
\hline TG & $=$ & thyroglobulin \\
\hline TGab & $=$ & thyroglobulin antibodies \\
\hline TPOab & $=$ & thyroperoxidase antibodies \\
\hline $\mathrm{ThCa}$ & $=$ & thyroid cancer \\
\hline $\mathrm{ThV}$ & $=$ & thyroid volume \\
\hline TRab & $=$ & thyrotropin receptor antibodies \\
\hline
\end{tabular}

$\mathrm{TSH}$

TT3

TT4

UDP

$$
\begin{array}{ll}
= & \begin{array}{l}
\text { thyroid stimulating } \\
\text { pin })
\end{array} \\
= & \text { total triiodothyronine } \\
= & \text { total thyroxine } \\
= & \text { uridyl diphosphate }
\end{array}
$$$$
\text { thyroid stimulating hormone (thyrotro- }
$$

\section{REFERENCES}

[1] Kočan A, Petrík J, Drobná B, Chovancová J. Levels of PCBs and some organochlorine pesticides in the human population of selected areas of the Slovak Republic. Chemosphere 1994; 29: 2315-25.

[2] Kočan A, Petrík J, Chovancová J, Drobná, B. Method for the group separation of non-ortho, mono-ortho and multi-ortho-substituted polychlorinated biphenyls and polychlorinated dibenzo-pdioxins/polychlorinated dibenzofurans using activated carbon chromatography. J Chromatogr 1994; A 665: 139-53.

[3] Kočan A, Petrík J, Jursa S, Chovancová J, Drobná, B. Environmental contamination with polychlorinated biphenyls in the area of their former manufacture in Slovakia. Chemosphere 2001; 93: 59560.

[4] Chovancová J, Kočan A, Jursa S. PCDDs, PCDFs and dioxin-like PCBs in food of animal origin (Slovakia). Chemosphere 2005; 61: 1305-11.

[5] Jursa S, Chovancová J, Petrík J, Lokša J. Dioxin-like and nondioxin-like PCBs in human serum of Slovak population. Chemosphere 2006; 64: 686-91.

[6] Petrík J, Drobná B, Pavúk M, Jursa S, Wimmerová S. Chovancová J. Serum PCBs and organochlorine pesticides in Slovakia: age, gender, and residence as determinants of organochlorine concentrations. Chemosphere 2006; 65: 410-18.

[7] Hovander L, Linderholm L, Athanasiadou M, et al. Levels of PCB and their metabolites in the serum of residents of a highly contaminated area in eastern Slovakia. Environ Sci Technol 2006; 40: 3696-703.

[8] Linderholm L, Park J-S, Kočan A, et al. Maternal and cord serum exposure to PCB and DDE methyl sulfone metabolites in eastern Slovakia. Chemosphere 2007; 69: 403-10.

[9] Park J-S, Bergman A, Linderholm L, et al. Placental transfer of polychlorinated biphenyls, their hydroxylated metabolites and pentachlorophenol in pregnant women from eastern Slovakia. Chemosphere 2008; 70: 1676-84.

[10] Park J-S, Linderholm L, Charles JM, et al. Polychlorinated biphenyls and their hydroxylated metabolites (OH-PCBs) in pregnant women from eastern Slovakia. Environ Health Perspect 2007; 115 : 20-7.

[11] Langer P, Kočan A, Tajtáková M, et al. Fish from industrially polluted freshwater as main source of organochlorinated pollutants and increased frequency of thyroid disorders and dysglycemia. Chemosphere 2007; 67: S379-85.

[12] Langer P, Tajtáková M, Kočan A, et al. Thyroid ultrasound volume, structure and function after long-term high exposure of large population to polychlorinated biphenyls, pesticides and dioxin Chemosphere 2007; 69: 118-27.

[13] Kortenkamp A. Ten years of mixing cocktails: A review of combination effects of endocrine-disrupting chemicals. Environ Health Perspect 2007; 115 (Suppl 1): 8-105.

[14] Murai K, Okamura K, Tsuji H, et al. Thyroid function in "Yusho" patients exposed to polychlorinated biphenyls (PCB). Environ Res 1987; 44: 179-87.

[15] Guo YL, Yu M-L, Lin L-Y, Hsu CC, Rogan WJ. Chloracne, goiter, arthritis and anemia after polychlorinated biphenyl poisoning: 14year follow-up of the Taiwan Yucheng cohort. Environ Health Perspect 1999; 107: 715-9.

[16] Tajtáková M, Hančinová D, Langer P, Tajták J, Malinovský E, Varga J. Thyroid volume in East Slovakian adolescents determined by ultrasound 40 years after the introduction of iodized salt. Klin Wochenschr 1988; 66: 749-51.

[17] Tajtáková M, Langer P. Retrospectively evaluated finding of larger thyroid volume in east Slovakian adolescents in 1987 than in 1992: Effect of Chernobyl? Horm Metab Res 1992; 25: 644-5.

[18] Tajtáková M, Langer P, Bohov P, Gonsorčíková V, Hančinová D. Recognition of a group of adolescents with rapidly growing thy- 
roids under iodine-replete conditions: seven year follow up. Eur J Endocrinol 1998; 138: 674-80.

[19] Tajtáková M, Semanová Z, Tomková Z, et al. Increased thyroid volume and frequency of thyroid disorders signs in schoolchildren from nitrate polluted area. Chemosphere 2006; 62: 559-64.

[20] Langer P, Tajtáková M, Fodor G, et al. Increased thyroid volume and prevalence of thyroid disorders in an area heavily polluted by polychlorinated biphenyls. Eur J Endocrinol 1998; 139: 402-9.

[21] Bahn AK, Mills JL, Snyder PJ, et al. Hypothyroidism in workers exposed to polybrominated biphenyls. N Engl J Med 1980; 302(1): 31-3.

[22] Langer P, Kočan A, Tajtáková M, et al. Possible effects of polychlorinated biphenyls and organochlorinated pesticides on the thyroid after long-term exposure to heavy environmental pollution. J Occup Environ Med 2003; 45: 526-32.

[23] Rádiková Z, Tajtáková M, Kočan A, et al. Possible effects of environmental nitrates and organochlorines on human thyroid in highly polluted areas in Slovakia. Thyroid 2007; 18: 353-62.

[24] Delange F, Benker G, Caron Ph, et al. Thyroid volume and urinary iodine in European schoolchildren: standardization of values for assessment of iodine deficiency. Eur J Endocrinol 1997; 136: 180-7.

[25] Langer P, Tajtáková M, Bohov P, Klimeš I. Possible role of genetic factors in thyroid growth rate and in the assessment of upper limit of normal thyroid volume in iodine-replete adolescents. Thyroid 1999; 9: 552-62

[26] Akoso BT, Sleight SD, Nachreiner RF, Aust SD. Effects of purified polybrominated biphenyl congeners on the thyroid and pituitary gland in rats. J Am Coll Toxicol 1982; 1: 23-36.

[27] Ness DK, Schantz SL, Moshtaghian J, Hansen L. Effects of perinatal exposure to specific PCB congeners on thyroid hormone concentrations and thyroid histology in the rat. Toxicol Lett 1993; 68: 311-23.

[28] Saeed A, Hansen L. Morphometric changes in the prepubertal female rat thyroid gland following acute exposure to $2,2^{\prime}, 4,4^{\prime}$ tetrachlorobiphenyl and Aroclor 1242. J Toxicol Environ Health 1997; 51: 503-13.

[29] Wade MG, Parent S, Finnson KW, et al. Thyroid toxicity due to subchronic exposure to a complex mixture of 16 organochlorines, lead, and cadmium. Toxicology 2002; 67: 207-18.

[30] Nishimura N, Yonemoto J, Miyabara Y, Sato M, Tohyama C. Rat thyroid hyperplasia induced by gestational and lactational exposure to 2,3,7,8-tetrachlorodibenzo-p-dioxin. Endocrinology 2003; 144: 207583 .

[31] Collins WT, Capen CC. Ultrastructural and functional alterations of the rat thyroid gland produced by polychlorinated biphenyls compared with iodide excess and deficiency, and thyrotropin and thyroxine administration. Virchow Arch B Cell Path 1980; 33;213-31.

[32] Capen CC, Martin SL. The effects of xenobiotics on the structure and function of thyroid follicular and C-cells. Toxicol Pathol 1989; 17: 266-93.

[33] Talsness CE, Kuriyama SN, Sterner-Kock A, et al. In utero and lactational exposures to low doses of polybrominated diphenyl ether-47 alter the reproductive system and thyroid gland of female rat offspring. Environ Health Perspect 2008; 116: 308-14

[34] Grimalt JO, Sunyer J, Moreno V, et al. Risk excess of soft-tissue sarcoma and thyroid cancer in community exposed to airborne organochlorinated compound mixtures with a high hexachlorobenzene content. Int J Cancer1994; 56: 200-3.

[35] Saracci R, Kogevinas M, Bertazzi PA, et al. Cancer mortality in workers exposed to phenoxy herbicides and chlorophenols. Lancet 1991; 338: 1027-32.

[36] Mallin K, McCann K, D'Aloisio A. Cohort mortality study of capacitator manufacturing workers, 1944-2000. J Occup Environ Med 2004; 46: $565-76$.

[37] Schreinemachers DM, Creason JP, Garry VF. Cancer mortality in agricultural regions of Minnesota. Environ Health Perspect 1999; 107: 205-11.

[38] Frich L, Akslen LA, Glattre E. Increased risk of thyroid cancer among Norwegian women married to fishery workers a retrospective cohort study. Br J Cancer 1997; 75: 385-9.

[39] Wolff MS, Camman D, Gammon M, Stellman SD. Proposed PCB congener groupings for epidemiological studies. Environ Health Perspect 1997; 105: 13-4.

[40] Hansen L. Stepping backward to improve assessment of PCB congener toxicities. Environ Health Perspect 1998; 106: 171-89.

[41] Kawabata W, Suzuki T, Moriya T. Estrogen receptors (alpha and beta) and 17beta-hydroxysteroid dehydrogenase type 1 and 2 in thyroid disorders: possible in situ estrogen synthesis and actions. Mol Pathol 2003; 16: 437-44.

[42] Tavangar SM, Monajemzadeh M, Larijani B, Haghpanah V. Immunochemical study of oestrogen receptors in 351 human thyroid glands. Singapore Med 2007; 48: 744-7.

[43] Shiraishi F, Okumura T, Nomachi M, et al. Estrogenic and thyroid hormone activity of a series of hydroxy-polychlorinated biphenyls. Chemosphere 2003; 52: 33-42

[44] Kitamura S, Jinno N, Suzuki T, et al. Thyroid hormone-like and estrogenic activity of hydroxylated PCBs in cell culture. Toxicology 2005; 208: 377-87.

[45] Matthews J, Gustafsson J-A. Estrogen receptor and aryl hydrocarbon receptor signaling pathways. Nucl Recept Signal 2006; 4: 1-4.

[46] Manole D, Schildknecht B, Gosnell B, Adams E, Derwahl M. Estrogen promote growth of human thyroid tumor cells by different molecular mechanisms. J Clin Endocrinol Metab 2001; 86: 1072-7.

[47] Kung AW, Chau MT, Lao TT, Tam SC, Low LC. The effect of pregnancy on thyroid hormone formation. J Clin Endocrinol Metab 2002; 87: 1010-4.

[48] Madej A, Persson E, Lundh T, Ridderstrale Y. Thyroid gland function in ovariectomized ewes exposed to phytoestrogens. J Chromatogr 2002; B 777: 281-7.

[49] Chen GG, Vlantis AC, Zeng Q, von Hasselt CA. Regulation of cell growth by estrogen signaling and potential targets in thyroid cancer. Curr Cancer Drug Targets 2008; 8: 367-77.

[50] Gougelet A, Mueller SO, Korach KS, Renoir JM. Oestrogen receptors pathways to oestrogen responsive elements: the transactivation function-1 acts as the keystone of oestrogen receptor (ER)beta-mediated transcriptional repression of ERalpha. J Steroid Biochem Mol Biol 2007; 104: 110-22

[51] Valle LD, Ramina A, Vianello S, Fassina A, Belvedere P, Colombo L. Potential for estrogen synthesis and action in human normal and neoplastic thyroid tissues. J Clin Endocrinol Metab 1998; 83: 3702 9.

[52] Persson I, Yuen J, Bergkvist L, Schairer C. Cancer incidence and mortality in women receiving estrogen and estrogen-progestin replacement therapy: long-term follow-up of Swedish cohort. Int $\mathbf{J}$ Cancer 1996; 67: 327-32.

[53] Tan Y, Chen CH, Lawrence D, Carpenter DO. Ortho-substituted PCBs kill cells by altering membrane structure. Toxicol Sci 2004; 80: 54-9.

[54] Yilmaz B, Sandal S, Chen CH, Carpenter DO. Effects of PCB 52 and PCB 77 on cell viability, $\left[\mathrm{Ca}^{2+}\right]$ levels and membrane fluidity in mouse lymphocytes. Toxicology 2006; 217: 184-91.

[55] Cheek AO, Kow K, Chen J, Chen J, McLachlan JA. Potential mechanisms of thyroid disruption in humans: interaction of organochlorine compounds with thyroid receptor, transthyretin, and thyroid binding globulin. Environ Health Perspect 1999; 107: 273-8.

[56] Chauhan KR, Kodavanti PRS, McKinney JD. Assessing the role of ortho-substitution on polychlorinated biphenyl binding to transthyretin, a thyroxine transport protein. Toxicol Appl Pharmacol 2000; 162: 10-21.

[57] Schuur AG, Brouwer A, Bergman A, Goughtrie MWH, Visser TJ. Inhibition of thyroid hormone sulfation by hydroxylated metabolites of polychlorinated biphenyls. Chem-Biol Interact 1998; 109: 293-7.

[58] Hood A, Klaasen CD. Differential effects of microsomal enzyme inducers on in vitro thyroxine (T4) and triiodothyronine (T3) glucuronidation. Toxicol Appl Pharmacol 2000; 163: 240-8.

[59] Byrne JJ, Carborne JP, Hanson EA. Hypothyroidism and abnormalities in the kinetics of thyroid hormone metabolism in rats treated chronically with polychlorinated biphenyl and polybrominated biphenyl. Endocrinology 1987; 21: 520-7.

[60] Wade MG, Parent S, Finnson, KW, et al. Thyroid toxicity due to subchronic exposure to a complex mixture of 16 organochlorines, lead, and cadmium. Toxicology 202; 67: 207-18.

[61] Baloch Z, Carayon P, Conte-Devolx B, et al:: ATA (American Thyroid Association), Guidelines Committee: Laboratory medicine practice guidelines for the diagnosis and monitoring of thyroid disease. Thyroid 2003; 13: 1-126.

[62] DeVito M, Biegel L, Brouwer A, et al. Screening methods for thyroid hormone disruptor. Environ Health Perspect 1999; 107: 407-15.

[63] Persky V, Turyk M, Anderson A, et al. The effects of PCB exposure and fish consumption on endogenous hormones. Environ Health Perspect 2001; 109: 1275-83. 
[64] Turyk ME, Anderson HA, Freels S, et al. Associations of organochlorines with androgenous hormones in male great lakes fish consumers and nonconsumers. Environ Res 2006; 102: 299-307.

[65] Turyk ME, Anderson HA, Persky VW. Relationship of thyroid hormones with polychlorinated biphenyls, dioxins, furans and DDE in adults. Environ Health Perspect 2007; 115: 1197-203.

[66] Abdelouhabab N, Mergler D, Takser L, et al. Gender differences in the effects of organochlorines, mercury, and lead on thyroid hormone levels in lakeside communities of Quebec (Canada). Environ Res 2008; 107: 380-92.

[67] Mazhitova Z, Jensen S, Ritzén M, Zetterström R. Chlorinated contaminants, growth and thyroid function in schoolchildren from the Aral Sea region in Kazachstan. Acta Paediatr 1998; 87: 991-5.

[68] Meeker JD, Altshul L, Hauser R. Serum PCBs, p,p'-DDE and HCB predict thyroid hormone levels in men. Environ Res 2007; 104: 296-301

[69] Donato F, Zani C, Magoni M, et al. Polychlorinated biphenyls and thyroid hormone serum concentrations among people living in a highly polluted area: A cross-sectional population-based study. Environ Res 2008; 108: 380-6.

[70] Sala M, Sunyer J, Herrero C, To-Figueras J, Grimalt J. Associations between serum concentrations of hexachlorobenzene and polychlorinated biphenyls with thyroid hormone and liver enzymes in a sample of general population. Occup Environ Med 2001; 58: $172-7$

[71] Osius N, Karmaus W, Kruse H, Witten J. Exposure to polychloinated biphenyls and levels of thyroid hormones. Environ Health Perspect 1999; 107: 845-9.

[72] Bloom MS, Weiner JM, Vena JE, Beehler GP. Exploring associations between serum level of select organochlorines and thyroxine in a sample of New York state sportsmen: The New York State Cohort Study. Environ Res 2003; 93: 52-66.

[73] Takser L, Mergler D, Baldwin M, de Grosbois S, Smargiassi A, Lafond J. Thyroid hormones in pregnancy in relation to environmental exposure to organochlorine compounds and mercury. Environ Health Perspect 2005; 11: 1039-45.

[74] Schell LM, Gallo M, DeCaprio AP, Hubicki L, Denham M, Ravenscroft $J$. Thyroid function in relation to burden of PCBs, p, p'-DDE, HCB, mirex and lead among Akwesasne Mohawk youth: a preliminary study. Environ Toxicol Pharmacol 2004; 18: 91-9.

[75] Hagmar L, Rylander L, Dyremark E, Klasson-Wehler E, Erfurth EM. Plasma concentrations of persistent organochlorines in relation to thyrotropin and thyroid hormone levels in women. Int Arch Occup Environ Health 2001; 74: 184-8.

[76] Hagmar L, Björk J, Sjödin A, Bergman A, Erfurth EM. Plasma levels of persistent organohalogens and hormone levels in adult male humans. Arch Environ Health 2001; 56: 138-43.

[77] Pelletier C, Doucet E, Imbeault P, Tremblay A. Associations between weight loss-induced changes in plasma organochlorine concentrations, serum T3 concentration, and resting metabolic rate. Toxicol Sci 2002; 67: 46-51.

[78] Langer P, Kočan A, Tajtáková M, et al. Possible effects of persistent organochlorinated pollutants cocktail on thyroid hormone levels and pituitary-thyroid interrelations. Chemosphere 2007; 70: 110-8.

[79] Rylander L, Wallin E, Jonsson BAG, Stridsberg M, Erfurth EM, Hagmar L. Associations between CB-153 and p, p'-DDE and hormone levels in serum in middle-aged and elderly men. Chemosphere 2006; 65: 675-81.

[80] Pluim HJ, de Viljder JJ, Olie K, et al. Effects of pre- and postnatal exposure to chlorinated dioxins and furans on human neonatal thyroid hormone concentration. Environ Health Perspect 1993; 101: 504-8.

[81] Koopman-Esseboom C, Morse DC, Weisglas-Kuperus N, et al. Effects of dioxins and polychlorinated biphenyls on thyroid hormone status of pregnant women and their infants. Pediatr Res 1994; 36: 468-76.

[82] Manji N, Boelaert K, Sheppard MC, Holdert RL, Gough SC, Franklyn JA. Lack of association between serum TSH or free T4 and body mass index in euthyroid subjects. Clin Endocrinol 2006; 64: $125-8$.

[83] Monaco F. Classification of thyroid diseases: suggestions for a revision. J Clin Endocrinol Metab 2003; 88: 1428-32.

[84] Hollowell JG, Staehling NW, Flanders WD, Gunter EW, Spencer CA, Braverman LE. Serum TSH, ${ }_{4}$, and thyroid antibodies in the United States population (1988 to 1994: National Health and Nutrition Ex- amination Survey (NHANES III). J Clin Endocrinol Metab 2002; 87: 489-99.

[85] Demers LM, Spencer CA. Laboratory medicine practice guidelines: laboratory support for the diagnosis and monitoring of thyroid disease. Clin Endocrinol 2003; 58:138-40.

[86] Wartofsky L, Dickey RA. The evidence for a narrower thyrotropin reference range in compelling. J Clin Endocrinol Metab 2005; 90: 5483-8.

[87] Canaris GJ, Manowitz MB, Mayor G, Ridgway EC. The Colorado Thyroid Disease Prevalence Study. Arch Int Med 2000; 160: 52634.

[88] Dallaire F, Dewailly E, Vézina C, et al. Effect of prenatal exposure to polychlorinated biphenyls on incidence of acute respiratory infections in preschool Inuit children. Environ Health Perspect 2006; 114: $1301-5$

[89] Heilmann C, Grandjean P, Weihe P. Decreased childhood vaccine response in children exposed to PCBs from maternal seafood diet. Organohalogen Compd 2003; 60-5: 1-4

[90] Baccarelli A, Mocarelli P, Patterson DG, et al. Immunologic effects of dioxin: New results from Seveso and comparison with other studies Environ Health Perspect 2002; 110: 1169-73.

[91] Cooper GS, Martin SA, Longnecker MP, Sandler DP, Germolec DR. Associations between plasma DDE levels and immunologic measures in African-American farmers in North Carolina. Environ Health Perspect 2004; 112: 1080-4.

[92] Bernhoft A, Skaare JU, Woog O, Derocher AE, Larsen HJS. Possible immunotoxic effects of organochlorines in polar bears (ursus maritimus) at Svalbard. J Toxicol Environ Health 2000; 59: 56174.

[93] Michielsen CCPPC, van Loveren H, Vos JG. The role of the immune system in hexachlorobenzene-induced toxicity. Environ Health Perspect 1999; 107 (Suppl. 5): 783-92.

[94] Tomer Y, Davies T. Searching for the autoimmune thyroid disease susceptibility genes: from gene mapping to gene function. Endocr Rev 2003; 24: 694-717.

[95] Langer P, Tajtáková M, Koška J, Bohov P, Šeböková E., Klimeš I. Multimodal distribution versus logarithmic transformation of thyroid volume in adolescents. Endocr J 2003; 50: 117-25.

[96] Vejbjerg P, Knudsen N, Perrild H, et al. The association between hypoechogenicity or irregular echo pattern at thyroid ultrasonography and thyroid function in the general population. Eur $\mathbf{J}$ Endocrinol 2006; 155: 547-52.

[97] Duntas LH. Subcinical thyroid disorders: the menace of the Trojan horse. Endocrinol Invest 2003; 26: 472-80.

[98] Feldt-Rasumussen U. Analytical and clinical performance goals for testing autoantibodies to thyroperoxidase, thyroglobulin, and thyrotropin receptos. Clin Chem 1996; 42: 160-3.

[99] Jaume JC, Guo J, Pauls D, et al. Evidence for genetic transmission of thyroid peroxidase antibody. J Clin Endocrinol Metab 1999; 84: 1424-31.

[100] Hobby P, Gardas A, Radomski R, Mc Gregor AM, Banga JP, Sutton BJ. Identification of an immunodominant region recognized by human autoantibodies in a three-dimensional model of thyroid peroxidase. Endocrinology 2000; 141: 2018-26.

[101] Schell LM, Gallo MV, Ravenscroft J, DeCaprio AP. Persistent organic pollutants and anti-thyroid peroxidase levels in Akwesasne young adults. Environ Res 2009; 109 (1): 8692.

[102] Henriksen GL, Ketchun NS, Michalek JE, Swaby JA. Serum dioxin and diabetes mellitus in veterans of operation Ranch Hand. Epidemiology 1997; 8: 252-8.

[103] Michalek JE, Akhtar FZ, Kiel JL. Serum dioxin, insulin, fasting glucose, and sex hormone-binding globulin in veterans of operation Ranch Hand. J Clin Endocrinol Metab 1999; 84: 1540-3.

[104] Cranmer M, Louie S, Kennedy RH, Kern PA, Fonseca VA. Exposure to 2,3,7,8-tetrachlorodibenzo-p-dioxin (TCDD) is associated with hyperinsulinism and insulin resistance. Toxicol Sci 2000; 56: 431-6.

[105] Kern PA, Said S, Jackson WG, Michalek JE. Insulin sensitivity following agent orange exposure in Vietnam veterans with high blood levels of 2,3,7,8-tetrachlorodibenzo-p-dioxin. J Clin Endocrinol Metab 2004; 89: 4665-72.

[106] Lee DH, Lee IK, Song K, et al. A strong dose-response relation between serum concentrations of persistent organic pollutants and diabetes. Diabetes Care 2006; 29: 1638-44.

[107] Everett CJ, Frithsen IL, Diaz VA, Koopman RJ, Simpson WM Jr, Mainous AG. Association of a polychlorinated dibenzo-p-dioxin, a 
polychlorinated biphenyl, and DDT with diabetes in the 1999-2002 National Health and Nutrition Examination Survey. Environ Res 2007; 103: 413-8.

[108] Rylander L, Wallin E, Jonsson BAG, Stridsberg M, Erfurth EM, Hagmar L. Associations between CB-153 and p,p'-DDE and hormone levels in serum in middle-aged and elderly men. Chemosphere 2006; 65: 675-81.

[109] Rignell-Hydbom A, Rylander L, Hagmar L. Exposure to persistent organochlorine pollutants and type 2 diabetes mellitus. Hum Exp Toxicol 2007; 26: 447-52.

[110] Saldana TM, Basso O, Hoppin JA, et al. Pesticide exposure and self-reported gestational diabetes mellitus in the Agricultural Health Study. Diabetes Care 2007; 30: 529-34.

[111] Wang SL, Tsai PC, Yang CY, Guo YL. Increased risk of diabetes and polychlorinated biphenyls and dioxins: a 24-year follow-up study of the Yucheng cohort. Diabetes Care 2008; 31: 1574-9.

[112] Klimeš I, Koška J, Kšinantová L, et al. Increased frequency of glucose intolerance in the population of specific areas of eastern Slovakia chronically exposed to contamination with polychlorinated biphenyls (PCB). 63rd ADA Scientific Sessions. Diabetes Abstr Book 2003; 52 (Suppl 1): 955-P.

[113] Rádiková Z, Koška J, Kšinantová L, et al. Increased frequency of diabetes and other forms of dysglycemia in the population of specific areas of eastern Slovakia chronically exposed to contamination with polychlorinated biphenyls (PCB). Organohalogen Compd 2005; 66: 3547-50.

[114] Liu PC, Matsumura F. Differential effects of 2,3,7,8-tetrachlorodibenzo-p-dioxin on the "adipose-type" and "brain-type" glucose transporters in mice. Mol Pharmacol 1995; 47: 65-73.

[115] Remillard RBJ, Bunce NJ. Linking dioxins to diabetes: Epidemiology and biological plausibility. Environ Health Perspect 2002; 110: 853-7.

[116] Hankinson O. Role of coactivators in transcriptional activation by the aryl hydrocarbon receptor. Arch Biochem Biophys 2005; 433: 379-86.

[117] Fujiyoshi PT, Michalek JE, Matsumura F. Molecular epidemiologic evidence for diabetogenic effects of dioxin exposure in U.S. Air Force veterans of the Vietnam war. Environ Health Perpect 2006; 114: 1677-83.

[118] Kimbrough RD, Krouskas CA. Polychlorinated biphenyls, dibenzo-pdioxins, and dibenzofurans and birth weight and immune and thyroid function in children. Regul Toxicol Pharmacol 2001; 34: 42-52.

[119] Schantz SL, Widholm JJ, Rice DC. Effects of PCB exposure on neuropsychological functions in children. Environ Health Perspect 2003; 11: 357-76.

[120] Tusscher ten GW, Koppe JG. Perinatal dioxin exposure and later effects - a review. Chemosphere 2004; 54: 1329-36.
[121] Wang RY, Needham L, Barr DB. Effects of environmental agents on the attainment of puberty: Considerations when assessing exposure to environmental chemicals in the national children's study. Environ Health Perspect 2005; 113: 1100-07. :

[122] Park H-Y, Hertz-Picciotto I, Petrík J, Palkovičová L, Kočan A, Trnovec T. Prenatal PCB exposure and thymus size at birth in neonates in Eastern Slovakia. Environ Health Perspect 2008; 116: 1049.

[123] Hertz-Picciotto I, Park H-Y, Dostal M, Kocan A, Trnovec T, Sram R. Prenatal exposures to persistent and non-persistent organic compounds and effects on immune system development. Basic Clin Pharmacol Toxicol 2008; 102: 146-54.

[124] Chen YJ, Yu M-L M, Rogan WJ, Gladen BC, Hsu CC. A 6-year follow-up of behavior and activity disorders in the Taiwan $\mathrm{Yu}-$ cheng children. Am J Public Health 1994; 84: 415-21.

[125] Grandjean P, Weihe P, Burse VW, et al. Neurobehavioral deficits associated with PCBs in 7 year old children prenatally exposed to seafood neurotoxicants. Neurotoxicol Teratol 2001; 12: 305-17.

[126] Walkoviak J, Wiener JA, Fastabend A, Heinzow B, Schmidt E Steingruber HJ. Environmental exposure to polychlorinated biphenyls and quality of the home environment: effects on psychodevelopment in early childhood. Lancet 2001; 359: 1602-7.

[127] Vreugdenhil HJ, Mulder PG, Emmen HH, Weisglas-Kuperus N. Effects of perinatal exposure to PCBs on neuropsychological functions in the Rotterdam cohort at 9 years of age. Neuropsychology 2004; 18: 185-93.

[128] Šovčíková E, Trnovec T, Wsolová L, et al. PCBs, Human and Environmental Disposition and Toxicology In: Hansen LG, Robertson LW, Eds: University of Illinois Press: Urbana and Chicago, USA 2008; pp. 95-100.

[129] Trnovec T, Sovcikova E, Hustak M, et al. Exposure to polychlorinated biphenyls and hearing impairment in children. Environ Toxicol Pharmacol 2007; 25: 183-7.

[130] Jan J, Sovcikova E, Kocan A, Wsolova L, Trnovec T. Developmental dental defects in children exposed to PCBs in eastern Slovakia. Chemosphere 2007; 67: S350-S353.

[131] Langer P, Kočan A, Tajtáková M, et al. Increased thyroid volume, prevalence of thyroid antibodies and impaired fasting glucose in young adults from organochlorine cocktail polluted area: Outcome of transgenerational transmission? Chemosphere 2008; 73: 114550 .

[132] Anway MD, Skinner MK. Epigenetic transgenerational actions of endocrine disruptors. Endocrinology 2006; 147: S43-S49.

[133] Zoeller RT. Endocrine disruptors: Do family lines carry an epigenetic record of previous generations' exposures? Endocrinology 2006; 147: 5513-4.

(C) Langer et al.; Licensee Bentham Open.

This is an open access article licensed under the terms of the Creative Commons Attribution Non-Commercial License (http://creativecommons.org/licenses/by-nc/3.0/) which permits unrestricted, non-commercial use, distribution and reproduction in any medium, provided the work is properly cited. 